\title{
Alkaline phosphatase activity related to phosphorus stress of microphytoplankton in different trophic conditions
}

\author{
Ingrid Ivančić ${ }^{\mathrm{a}, *}$, Martin Pfannkuchen ${ }^{a}$, Jelena Godrijan ${ }^{\mathrm{a}}$, Tamara Djakovac ${ }^{\mathrm{a}}$, Daniela Marić Pfannkuchen ${ }^{\mathrm{a}}$, \\ Marino Korlević ${ }^{a}$, Blaženka Gašparović ${ }^{b}$, Mirjana Najdek ${ }^{a}$ \\ ${ }^{a}$ Center for Marine Research, Ruđer Bošković Institute, G. Paliaga 5, HR-52210 Rovinj, Croatia \\ ${ }^{\mathrm{b}}$ Division for Marine and Environmental Research, Ruđer Bošković Institute, Bijenička 54, HR-10002 Zagreb, Croatia
}

\section{A R T I C L E I N F O}

\section{Article history:}

Received 11 February 2016

Received in revised form 5 July 2016

Accepted 5 July 2016

Available online 12 July 2016

\begin{abstract}
A B S T R A C T
The northern Adriatic (NA) is a favorable basin for studying the adaptive strategies of plankton to a variety of conditions along the steep gradients of environmental parameters over the year. Earlier studies identified phosphorus (P)-limitation as one of the key stresses within the NA that shape the biological response in terms of biodiversity and metabolic adjustments. A wide range of reports supports the notion that P-limitation is a globally important phenomenon in aquatic ecosystems. In this study P stress of marine microphytoplankton was determined at species level along a trophic gradient in the NA. In P-limitation all species with considerable contributions to the diatom community expressed alkaline phosphatase activity (APA), compared to only a few marginal dinoflagellate species. Nevertheless, APA expressing species did not always dominate the phytoplankton community, suggesting that APA is also an important strategy for species to survive and maintain active metabolism outside of their mass abundances. A symbiotic relationship could be supposed for diatoms that did not express APA themselves and probably benefited from APA expressed by attached bacteria. APA was not expressed by any microphytoplankton species during the autumn when $P$ was not limiting, while most of the species did express APA during the P-limitation. This suggests that APA expression is regulated by orthophosphate availability. The methods employed in this study allowed the microscopic detection of APA for each microphytoplankton cell with simultaneous morphologic/taxonomic analysis. This approach uncovered a set of strategies to compete in P-limited conditions within the marine microphytoplankton community. This study confirms the role of P-limitation as a shaping factor in marine ecosystems.
\end{abstract}

(c) 2016 Elsevier Ltd. All rights reserved.

\section{Introduction}

Growing evidence suggests that phosphorus $(\mathrm{P})$ is frequently the limiting nutrient in coastal systems (Thingstad et al., 1993, 1998) and oligotrophic oceans (Cotner et al., 1997; Karl and Yanagi, 1997). Furthermore, it is believed that the open ocean, far from the continental inputs of nutrients, should evolve toward P-limited conditions due to $\mathrm{N}_{2}$ fixation, while $\mathrm{P}$ is a non-renewable limiting nutrient (Tyrrell, 1999). The rise in $\mathrm{N}_{2}$ fixation and the simultaneous disappearance of $\mathrm{P}$ stocks observed in the subtropical North Pacific Ocean between 1989 and 2004 is an illustration of this phenomenon (Karl et al., 2001; Karl, 2007). Therefore, the importance of alkaline phosphatase activity (APA) with regard to the transformation and turnover of organic compounds in marine environments has been investigated with growing attention (for review see Hoppe, 2003; Yamaguchi and Adachi, 2010).

\footnotetext{
* Corresponding author.

E-mail address: ingrid@cim.irb.hr (I. Ivančić).
}

A number of studies in the northern Adriatic (NA) evidenced that this region is currently P-limited (citations reported in the following text). This shallow (up to $50 \mathrm{~m}$ ) coastal sea is characterized by significant freshwater input, mainly from the Po River. Although in the Po River waters both nitrogen $(\mathrm{N})$ and $\mathrm{P}$ concentrations (total nitrogen $263 \mu \mathrm{mol} \mathrm{L}^{-1}$ and total phosphorus $4.8 \mu \mathrm{mol} \mathrm{L}^{-1}$; Cozzi and Giani, 2011) are more than one order of magnitude higher than in the NA waters, the inorganic N:P molar ratio (about 84:1; Cozzi and Giani, 2011) provides a strongly unbalanced $N$ versus $P$ supply for phytoplankton requirements (presumed balanced $\mathrm{N}: \mathrm{P}=16: 1$; Redfield et al., 1963). Earlier studies in this area showed that organic phosphorus concentrations markedly exceeded orthophosphate $\left(\mathrm{PO}_{4}\right)$ concentrations, representing an important source of $\mathrm{P}$ for microbial communities (Ivančić and Degobbis, 1987). A significant contribution to the pool of dissolved P in the NA could be due to the release of dissolved DNA by nanoflagellates grazing on nucleic acid-rich bacterial biomass (Turk et al., 1992). These authors reported that during stratified conditions a significant part of the P demand by the autotrophs may be sustained by the rapid 
turnover of DNA-mediated release of inorganic phosphorus. The importance of dissolved organic phosphorus (DOP) in the area during periods of P-limitation was evidenced also by a recent mesocosm experiment (Malfatti et al., 2014). However, the authors pointed out that not all DOP is directly hydrolysable by alkaline phosphatase (AP) and multiple hydrolase activities were available with potential to transform various organic matter pools into molecules accessible to AP and other hydrolases that are the terminal step in $\mathrm{P}$ regeneration.

Bioassays based on selective nutrient additions and nutrient molar ratios identified P-limitation of the NA (Maestrini et al., 1997 and citation therein). Enzyme assays with soluble substrate showed that extracellular AP is important in providing $\mathrm{P}$ for phytoplankton growth, particularly during blooms induced by freshwater imported nutrients (Ivančić et al., 2009, 2010). However, although measurements with soluble substrate allowed detection of the phytoplankton P status, they provided only the APA of the whole community and did not yield information on the individual species. Furthermore, it was not possible to mark the exact location of the enzymatic activity in the cells or to determine the contribution of each species to the overall enzyme signal.

In the present study an AP substrate with insoluble fluorogenic product, termed ELF (Enzyme Labelled Fluorescence), was used to investigate how the APA status varies among phytoplankton species at two locations along the trophic gradient. This method yields a stable, highly fluorescent precipitate at the site of enzyme activity and thus has the capability to determine the APA status of individual cells (González-Gill et al., 1998). Hence, it can give insights into the mechanisms of $\mathrm{P}$ nutrition of phytoplankton in natural waters. In the previous study it was found that low $\mathrm{PO}_{4}$ concentrations can modify the structure of plankton communities and constrain the phytoplankton distribution (Ivančić et al., 2012) as also reported for other areas (Egge, 1998; Moutin et al., 2005; Mackey et al., 2007). In addition P-limitation can affect phytoplankton abundance and composition, viral and prokaryotic abundance, microbial activity and organic matter production and utilization (Larato et al., 2010). However, not all microorganisms are equally affected. By comparing estimated taxon-specific C:P utilization rates with particulate $\mathrm{C}: \mathrm{P}$ ratios in P-replete and P-deplete cultures it was shown that different phytoplankton groups experienced different degrees of P stress in the same nutrient environment (Casey et al., 2009).

In this study, investigations are concentrated on microphytoplankton as it is often the dominating component of the phytoplankton community biomass in the NA (Center for Marine Research, unpubl. data) and it is taxonomically well defined. Microphytoplankton also seems to play the major role in benthic pelagic coupling in the area (Pfannkuchen et al., 2009, 2010). This study aims to answer the questions: do all microphytoplankton species unequivocally contribute to the bulk APA? Or perhaps, are there alternative strategies to cope with the gradients of P-availability in the NA? Another covered topic is the behavior in the planktonic community of (i) species which do follow the observed bulk APA and (ii) species which follow alternative strategies to cope with P-limitation.

\section{Methods}

\subsection{Sampling strategy}

Measurements were carried out at two stations (SJ101, RV001) in the northern Adriatic (Fig. 1) during eight cruises performed from March to November 2013. These stations were specifically chosen as they are in areas with different nutrient regimes. SJ101 (bottom depth $32 \mathrm{~m}$ ), situated in the western area, is usually under

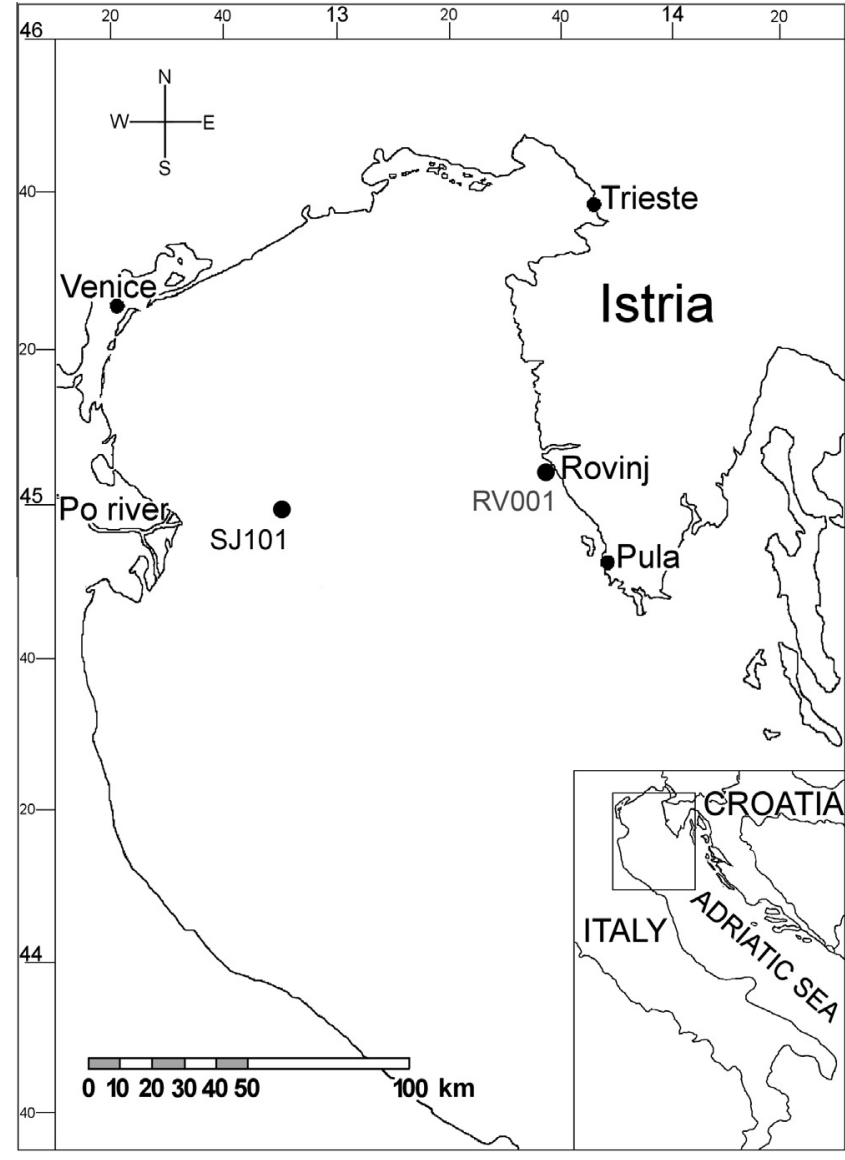

Fig. 1. Research area and sampling stations in the northern Adriatic Sea.

riverine nutrient pressure while RV001 (bottom depth $27 \mathrm{~m}$ ), situated in the eastern coastal area, is only intermittently experiencing freshwater influence. Further, SJ101 is usually under more direct freshwater nutrient influence, while freshwater reaching RV001 is already impoverished from nutrients.

During all cruises sea temperature and salinity were determined with an SBE25 conductivity-temperature-depth probe (Sea-Bird Electronics, Washington, USA). Samples for analysis of nutrients, bulk APA, and phytoplankton were collected with $5 \mathrm{~L}$ Niskin bottles at three depths (surface i.e. 0-1 m, $10 \mathrm{~m}$, and $2 \mathrm{~m}$ above the bottom). Samples for the determination of single cell APA (ELF assay) were collected by vertical tow of the phytoplankton net (pore size $20 \mu \mathrm{m}$ ) from 10 to $0 \mathrm{~m}$ depth (i.e. upper waters). Data for the daily Po flow mean measured at Pontelagoscuro, Italy, were kindly supplied by Assessorato Programmazione, Pianificazione e Ambiente of the Emilia Romagna region (Italy).

\subsection{Analytical protocol}

Inorganic nutrient analyses were performed onboard, immediately after sample collection, using methods described earlier (Strickland and Parsons, 1972; Ivančić and Degobbis, 1984). Samples for total dissolved phosphorus were filtered (Whatman $\mathrm{GF} / \mathrm{F}$, precombusted at $500^{\circ} \mathrm{C}$ ) and stored in autoclavable polypropylene tubes at $-30^{\circ} \mathrm{C}$. In the laboratory ashore analyses were performed using a wet combustion oxidation method with persulphate (Menzel and Corwin, 1965). DOP was calculated by subtracting $\mathrm{PO}_{4}$ from the total dissolved phosphorus. Dissolved inorganic nitrogen (DIN) was calculated as the sum of nitrate, nitrite and ammonia. 
Determination of APA was performed aboard the research vessel immediately after sample collection. Sea water $(5 \mathrm{~mL}$ per one sample) was filled into plastic syringes directly from samplers and filtered through a $200 \mu \mathrm{m}$ mesh (to remove mesozooplankton), $3 \mu \mathrm{m}$ (polycarbonate Nuclepore filter, Whatman) and $0.22 \mu \mathrm{m}$ filters (mixed cellulose esters Millipore membrane filter, Millex-GS). All filtrations were performed manually and gently applying light pressure using manual Millipore filter units. Determined activity in the $0.22 \mu \mathrm{m}$ filtrate was very low and in upper waters often below the detection limit, thus indicating that gentle filtration did not cause cell rupture. Filters of $3 \mu \mathrm{m}$ were preferred (passing through both bacteria and picocyanobacteria) instead of $2 \mu \mathrm{m}$ at which an unknown part of picocyanobacteria is retained. The nanophytoplankton fraction was retained on the $3 \mu \mathrm{m}$ filter as confirmed by microscopic inspection. The phytoplankton APA was calculated by subtracting activity in the $3 \mu \mathrm{m}$ from the activity in the $200 \mu \mathrm{m}$ filtrate.

All APA measurements were performed using the fluorogenic substrate analog methyllumbelliferyl-phosphate (MUF-P) dissolved in methylcellosolve and diluted with water immediately before addition, following the procedure of Hoppe (1983). Aliquots of $5 \mathrm{~mL}$ of all the filtrates, in duplicate, were used for APA measurements. The final concentration of the substrate in the samples was $50 \mu \mathrm{mol} \mathrm{L}^{-1}$ (Ivančić et al., 2009). Incubation of the samples was performed in dark in baths filled with water from the sampling depths, i.e. at in situ temperature. Fluorescence was measured immediately after substrate addition and after $\sim 1 \mathrm{~h}$ of incubation using a Turner Designs-700 fluorometer with excitation at $365 \mathrm{~nm}$ and emission at $460 \mathrm{~nm}$. APA ( $\left.\mathrm{nmol} \mathrm{L}^{-1} \mathrm{~h}^{-1}\right)$ was calculated as the difference between those measurements divided by the incubation time after calibration of the fluorometer with methyllumbelliferone, the product of MUF-P degradation. Additionally, in the $200 \mu \mathrm{m}$ filtrate, single measurements were performed using various MUF-P concentrations: from $0.5 \mu \mathrm{mol} \mathrm{L}^{-1}$ to $50 \mu \mathrm{mol} \mathrm{L}^{-1}$. Those measurements were used to determine the half saturation constant $\left(K_{\mathrm{m}}\right)$ and maximum activity $\left(V_{\max }\right)$ of the Michaelis-Menten kinetics, employing the Wolf-Hanes linearization. $\mathrm{P}$ turnover time $(T)$ was estimated by the $K_{\mathrm{m}}: V_{\max }$ ratio (Labry et al., 2005).

Single cell APA was detected utilizing the $\operatorname{ELF}^{\circledR} 97$ Endogenous Phosphatase Detection Kit (E6601) (Thermo Fisher Scientific, Waltham, USA). Cells were fixed in 3.5\% buffered ( $\mathrm{pH} 8$ ) formaldehyde at $4{ }^{\circ} \mathrm{C}$ for $30 \mathrm{~min}$ and not permeabilized with detergents as suggested by the ELF-kit manufacturer. Afterward, cells were rinsed in sterile seawater and subjected to microscopic analysis. ELF substrate was diluted 20 -fold in detection buffer and mixed with fixed cells to reach a final dilution of 40 -fold, directly prior to microscopic examination. Chloroplast autofluorescence was recorded at $580-600 \mathrm{~nm}$ (555 nm excitation) and ELF signal at $550-555 \mathrm{~nm}$ (405 nm excitation) on a Zeiss (Oberkochen, Germany) LSM (laser scanning microscope) 700 setup. Nominal thickness of optical sections under confocal conditions was $1.2 \mu \mathrm{m}$. Thresholding signal intensity and three dimensional signal reconstructions allowed to identify cell surface associated signal after the analysis of axial cross sections and correction for signal point spread functions (ZEN black, Zeiss). When an ELF positive cell was found, the species was determined and 99 additional intact cells of the same species were examined for ELF signal. Cells with leaking cytoplasm or without chloroplasts were disregarded. Each cell was tallied as either positive or negative for ELF labelling on the basis of the presence or absence of the fluorescent ELF ${ }^{\circledR} 97$ precipitate. Cells were regarded as ELF positive as soon as an ELF signal (signal intensity above the threshold as determined from the negative controls without addition of substrate) was located on the cell surface. The average standard error for triplicate counts for 100 cells using the LLF $^{\circledR}$-97 labelling technique was determined to be 3\% (Dyhrman and Palenik, 1999), and a similar error is expected in the present study. The respective figures show tangential optical sections best representing cell surface associated ELF signal.

Samples for the determination of phytoplankton composition and relative abundance were filtered through a $200 \mu \mathrm{m}$ mesh to remove zooplankton, and filtrates were preserved with formaldehyde solution ( $2 \%$ final concentration) buffered with sodium acetate. After $38 \mathrm{~h}$ sedimentation of $50 \mathrm{~mL}$ of filtrate, cell counts were performed on an inverted Axiovert 200 microscope (Zeiss $\mathrm{GmbH}$ ) following the Utermöhl method (1958). During counting, phytoplankton cells were attributed to microplankton or nanoplankton fractions, based on observed cell dimensions (Sieburth et al., 1978) and counted at $200 \times$ and $400 \times$ magnifications, respectively. Phytoplankton cells were identified at the lowest possible taxonomical rank. Diatoms and dinoflagellates within microphytoplankton were determined on the level of species.

Comparison of the contribution of ELF labelled organisms in microphytoplankton communities with bulk APA in fraction $>3 \mu \mathrm{m}$ was tested using least square linear regression and principal component factor analysis (PCA). One-way ANOVA was performed in order to test if there was a difference between the contribution of ELF labelled species in P-limited and P-repleted conditions. The conditions of normal distribution were tested with the ShapiroWilk test.

\section{Results}

\subsection{Hydrological conditions, nutrient status and phytoplankton community composition}

From March to the end of June the Po River flow was high (on average $3023 \mathrm{~m}^{3} \mathrm{~s}^{-1}$ ) with maximal impulses up to $7120 \mathrm{~m}^{3} \mathrm{~s}^{-1}$ in May (Fig. 2A). At the end of June the Po flow decreased to typical summer values and remained relatively constant until the end of October (in average $1070 \mathrm{~m}^{3} \mathrm{~s}^{-1}$ ), with frequent small impulses (up to $1437 \mathrm{~m}^{3} \mathrm{~s}^{-1}$ ). From the end of October the Po flow increased up to $2743 \mathrm{~m}^{3} \mathrm{~s}^{-1}$ at the end of November.

In March the entire water columns at both stations were cold $\left(9.78-10.65^{\circ} \mathrm{C}\right.$ ) and almost homogenous (Fig. 2B). During April-August, temperatures gradually increased $\left(13.21-24.67{ }^{\circ} \mathrm{C}\right.$ at the surface and $10.05-17.70^{\circ} \mathrm{C}$ at the bottom) with the establishment of thermal stratification at both stations, being the sharpest between the depths of 12 and $20 \mathrm{~m}$. From September a progressive cooling of the surface waters $\left(21.84-14.15^{\circ} \mathrm{C}\right.$; Fig. 2B) started a progressive mixing in the water columns. At the end of November temperature of the water columns was homogenous.

At SJ101 freshwater influence, extending down to $10-15 \mathrm{~m}$, was considerable during the whole studied period (surface salinity 15.90-36.54) (Fig. 2C). At RV001, freshwater influence was detected during May-October (surface salinity 35.82-37.00) extending down to 5-15 m, while in March-April and November it was low (surface salinity 37.21-37.54; Fig. 2C). In deeper layers of both stations more saline water was observed during the whole investigation period (salinity 37.20-38.41).

$\mathrm{PO}_{4}$ concentrations at RV001 were exceptionally low $\left(<0.03 \mu \mathrm{mol} \mathrm{L}^{-1}\right.$; Fig. 3A; S1A $)$ in the entire water column. At the surface of SJ101 somewhat higher $\mathrm{PO}_{4}$ concentrations were found during freshets in early spring and autumn (March-April, October-November; $\left.0.07-0.17 \mu \mathrm{mol} \mathrm{L}^{-1}\right)$, while during the summer values were exceptionally low $\left(<0.03 \mu \mathrm{mol} \mathrm{L}^{-1}\right)$. At this station a moderate accumulation of $\mathrm{PO}_{4}$ in the bottom waters started with the onset of stratification in May and persisted during the summer and autumn $\left(0.05-0.16 \mu \mathrm{mol} \mathrm{L}^{-1}\right.$; Fig. S1A). DOP concentrations $\left(0.10-0.59 \mu \mathrm{mol} \mathrm{L}^{-1}\right)$ always exceeded those of $\mathrm{PO}_{4}$ (Fig. 3A; S1B) 

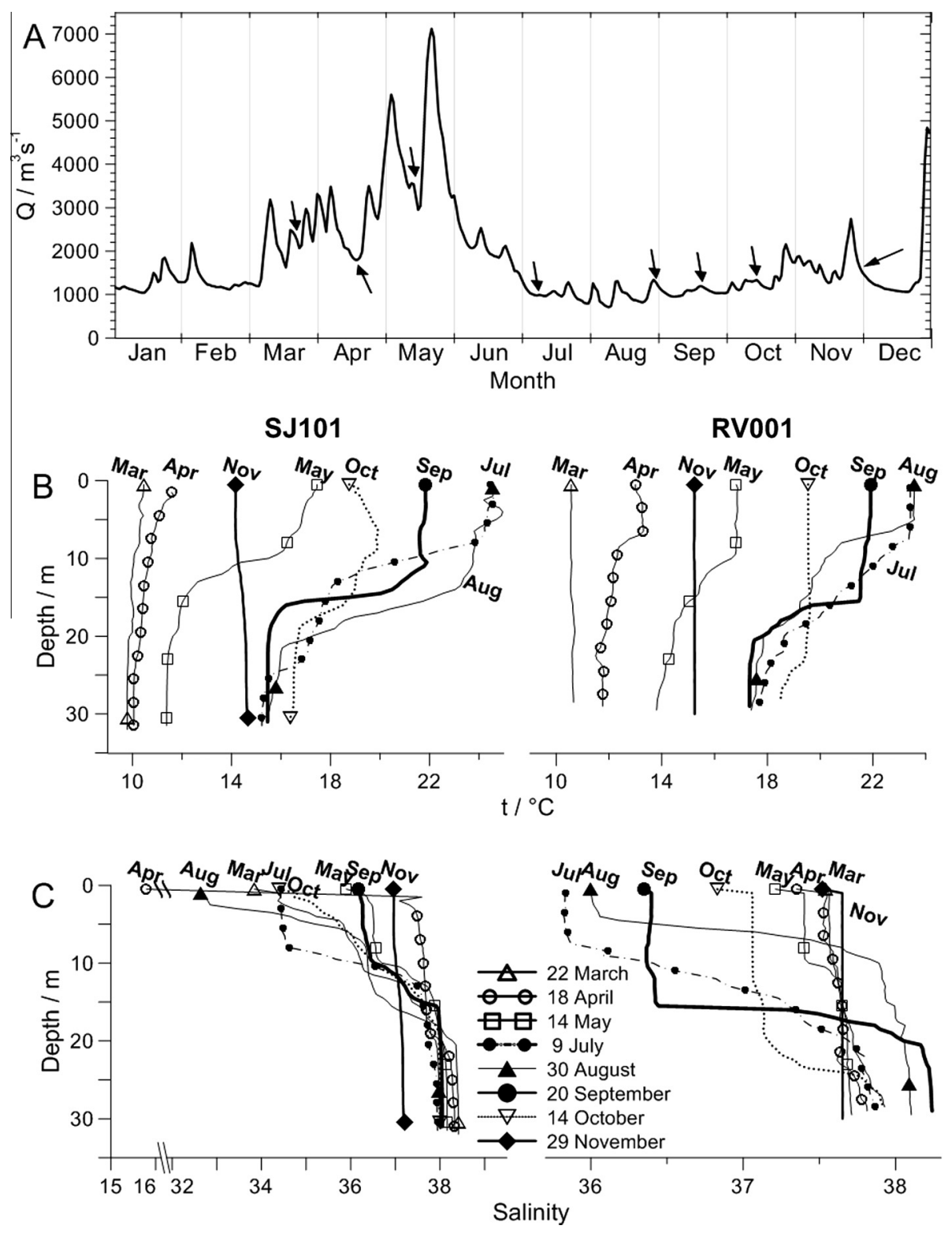

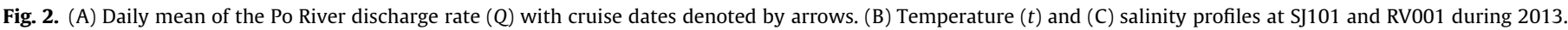

at both stations. Lower DOP concentrations were characteristic for summer and autumn, while during spring they were markedly higher.

During summer, DIN concentrations $\left(0.77-1.18 \mu \mathrm{mol} \mathrm{L}^{-1}\right)$ in upper waters of both stations (Fig. 3A, S1C) were markedly lower than in spring and autumn (1.75-4.28 and 2.57-76.15 $\mu \mathrm{mol} \mathrm{L}^{-1}$ at RV001 and SJ101, respectively), with the highest values during the spring freshets at SJ101. At SJ101, a moderate accumulation of DIN was observed in the bottom waters during the summer (up to $5.88 \mu \mathrm{mol} \mathrm{L}^{-1}$ ), while at RV001 no significant variation with depth was observed (S1C).

At the surface and $10 \mathrm{~m}$ depth at both stations DIN was present in marked surplus with respect to $\mathrm{PO}_{4}$ (average inorganic $\mathrm{N}: \mathrm{P} \sim 200$ ). In bottom waters they were generally more balanced for phytoplankton requirements (average inorganic $\mathrm{N}: \mathrm{P} \sim 21$ ).

The phytoplankton abundance was in the range of $\sim 10^{4}-10^{6}$ cell L $^{-1}$ (Fig. 3B; S2). The highest abundances were found in the surface waters and generally decreased with depth. The highest abundances were found from March to May in upper

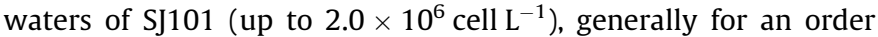

of magnitude higher than at RV001. From July to November the abundances were generally similar at both stations $\left(5.2 \times 10^{4}-4.8 \times 10^{5}\right.$ cell $\left.\mathrm{L}^{-1}\right)$. In the bottom waters, phytoplankton abundance $\left(2.8 \times 10^{4}-1.5 \times 10^{5}\right.$ cell L $\left.^{-1}\right)$ was lower than in upper waters and without noteworthy changes during the year or by station (Fig. S2C).

Generally, the phytoplankton community at both stations was dominated by the microphytoplankton in the upper waters, while the nanophytoplankton was dominating at the bottom (Fig. 3B; S2). Diatoms were generally much more abundant than dinoflagellates. In the microphytoplankton, diatoms and dinoflagellates were the two most diverse and abundant groups, while other groups accounted for $<3 \%$ of the respective community. During spring (March-April) the community composition in upper waters differed between the two stations (Fig. 3B). Microphytoplankton, comprised of almost only diatoms, strongly predominated at SJ101 (91\%), while at RV001 domination of nanophytoplankton (75-98\%) was recorded. In May-November the phytoplankton community composition was rather similar at both stations. During May and July nanophytoplankton dominated in the 

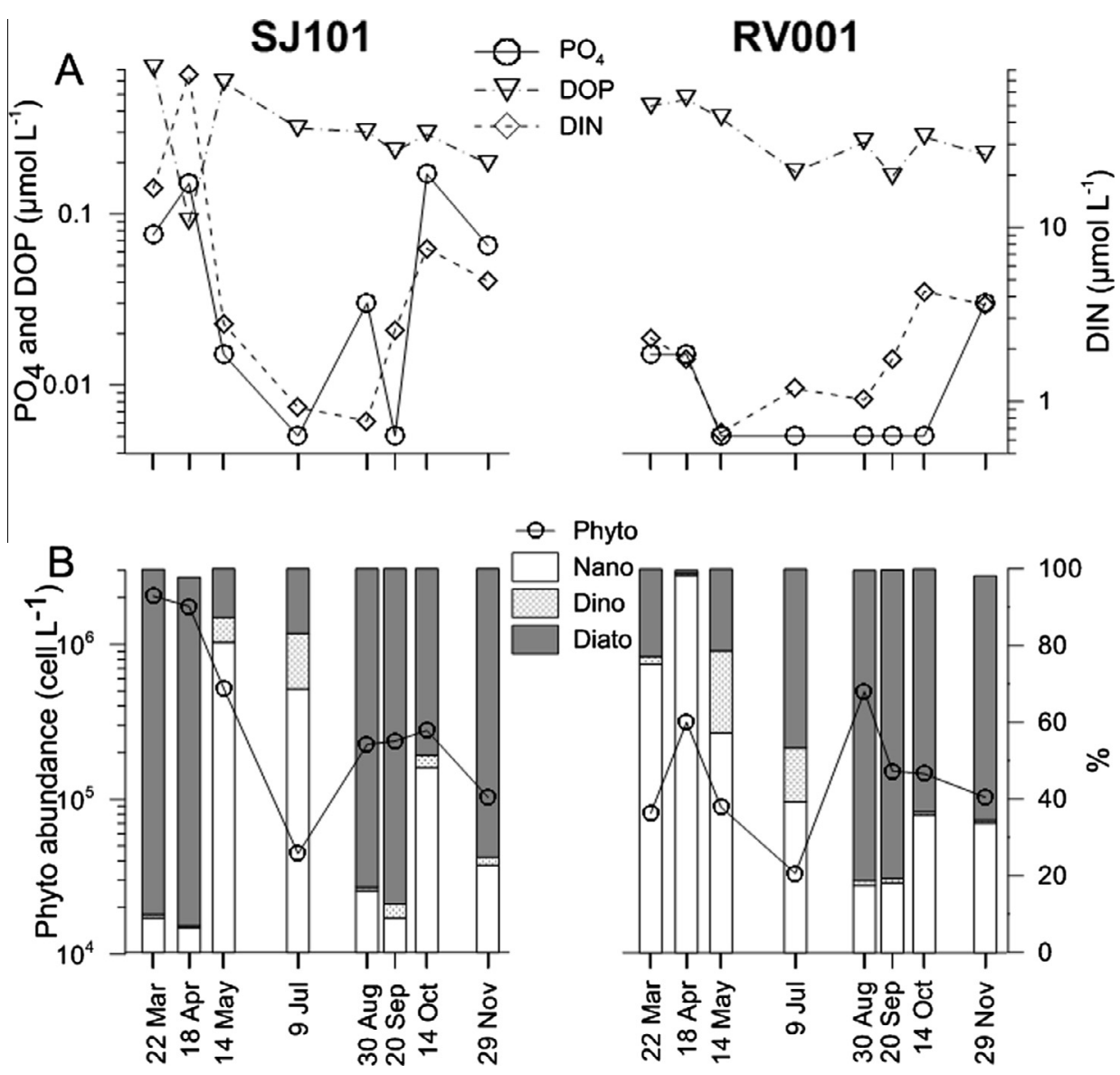

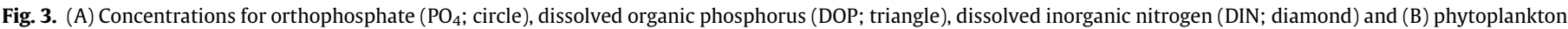
abundance (phyto) and community composition at surface of SJ101 and RV001 during 2013.

community, especially at SJ101 (60-80\%). Dinoflagellates during this period reached their maximal contribution at both stations (10-22\% and $6-16 \%$ at RV001 and SJ101, respectively). During August-November diatoms strongly predominated (generally 70$90 \%)$, while dinoflagellates accounted for a minor part of the community $(0.2-4.6 \%)$.

\subsection{APA and P turnover time}

In upper waters bulk APA gradually increased from March to high summer values (Fig. 4A; S3; up to 362.8 and $2916 \mathrm{nmol} \mathrm{L}^{-1} \mathrm{~h}^{-1}$, at RV001 and SJ101, respectively). During these months, values at SJ101 were constantly higher than at RV001, especially in March when APA at RV001 was exceptionally low $\left(<10 \mathrm{nmol} \mathrm{L}^{-1} \mathrm{~h}^{-1}\right)$. In autumn (October-November) a decrease in APA was observed (18.8 and $53.8 \mathrm{nmol} \mathrm{L}^{-1} \mathrm{~h}^{-1}$ at SJ101 and RV001, respectively). In upper waters most of bulk APA was observed in the fraction $>3 \mu \mathrm{m}$ (phytoplankton fraction; generally 70-90\%), except in November when most of the activity was found in the fraction $<3 \mu \mathrm{m}$ (Fig. 4A). At the bottom, APA was generally for an order of magnitude lower than in upper waters (Fig. S3C).

APA-mediated $\mathrm{PO}_{4}$ turnover time $(T)$ at the bottom was generally far above $5 \mathrm{~h}$ (up to $135 \mathrm{~h} ; 4 \mathrm{~B}$ ), indicating that phytoplankton was not P-limited (Nausch et al., 2004; Xu et al., 2008). On the contrary, in upper waters $T$ was generally below $5 \mathrm{~h}$, with exceptionally low values in August at the surface of SJ101 (about $1 \mathrm{~min}$ ), indicating P-limitation. In surface waters $T>5 \mathrm{~h}$ were observed only in March at RV001 (about $63 \mathrm{~h}$ ), then in October and November at both stations (17-257 h), indicating that P-limitation did not occur.

ELF signal was found localized around associated bacteria (Fig. 4Ca), diffused across the cell surface (Fig. 4Cb), in irregular shaped structures on the cell surface (Fig. 4Cc), in regular shaped islands on the cell surface (Fig. 4Cd), in small aggregations across the cell surface (Fig. 4Ce, f), diffusely associated with chloroplasts but on the cell surface (Fig. $4 \mathrm{Cg}$ ) and in regular shaped cell surface islands associated to chloroplast (Fig. 4Ch).

In the microphytoplankton community a variety of diatoms showed a positive ELF signal (Table 1). The lowest contribution of ELF positive species in diatom community (about 15-38\%) was found during spring at RV001 (Fig. 5A and B).

In March, during the water column mixing, only few species in relatively low abundance (Chaetoceros constrictus, Cerataulina pelagica, Thalassiosira sp.), and in April the dominant Chaetoceros circinalis, showed ELF signal at RV001 (Fig. 5A and B). Chaetoceros brevis was not ELF labelled, but bacteria attached to it showed strong ELF signal (Fig. 5A). Neither the dominant species Bacteriastrum furcatum in March nor the co-dominant Cerataulina pelagica in April were ELF labelled. Contrary, during the spring freshets at SJ101 the dominant Skeletonema marinoi, as well as the major part of diatom species (up to 99.5\% in diatom community), showed ELF signal (Fig. 5A and B). The co-dominant Chaetoceros socialis was ELF positive in April, but not in March when bacteria attached to it had a strong positive signal. In May the diatom community was strongly dominated by ELF labelled species (about 83-91\%) at both stations (Fig. 5C). During summer the maximal number of ELF labelled species was found (Fig. 6). The dominant species were 

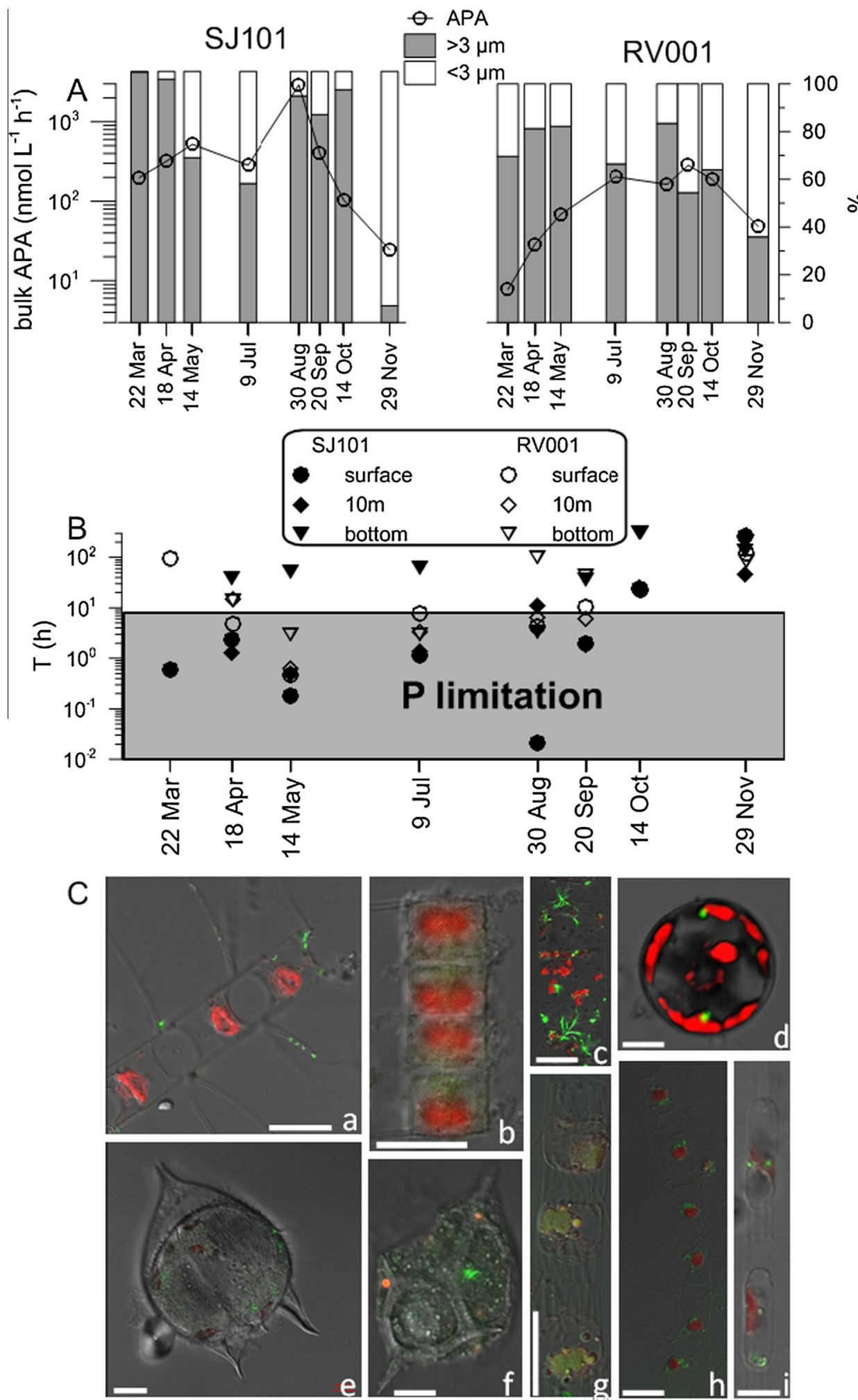

Scale bars represent $10 \mu \mathrm{m}$.

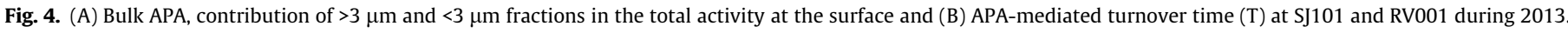

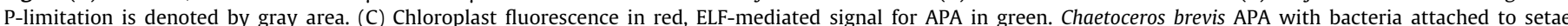

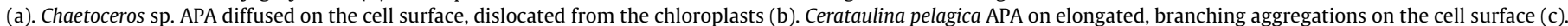

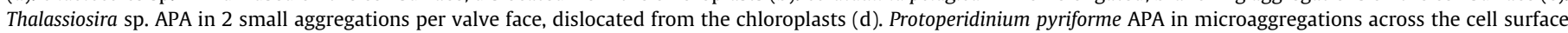

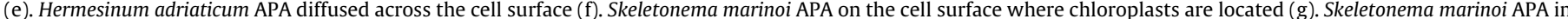

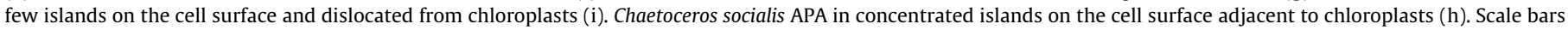
represent $10 \mu \mathrm{m}$. (For interpretation of the references to color in this figure legend, the reader is referred to the web version of this article.) 
Table 1

ELF detection of extracellular alkaline phosphatase activity in microphytoplankton species at SJ101 and RV001 during 2013. ELF positive species (+), ELF negative species $(-)$ and species where the ELF signal is located at attached bacteria (a).

\begin{tabular}{|c|c|c|c|}
\hline DIATOMS & ELF & DINOFLAGGELATES & ELF \\
\hline Asterionella formosa & - & Alexandrium minutum & - \\
\hline Asteromphalus heptactis & - & Ceratium candelabrum & - \\
\hline Bacteriastrum furcatum & + & Ceratium extensum & - \\
\hline Bacteriastrum hyalinum & + & Ceratium falcata & - \\
\hline Bacteriastrum jadranum & - & Ceratium furca & + \\
\hline Bacteriastrum mediterraneum & - & Ceratium furca var. eugrammum & - \\
\hline Cerataulina pelagica & + & Ceratium fusus & - \\
\hline Chaetoceros affinis & - & Ceratium hexacanthum & - \\
\hline Chaetoceros brevis & $\mathrm{a}$ & Ceratium pavillardi & - \\
\hline Chaetoceros circinalis & + & Ceratium symmetricum & - \\
\hline Chaetoceros concavicornis & - & Ceratium trichoceros & + \\
\hline Chaetoceros constrictus & + & Ceratium tripos & - \\
\hline Chaetoceros curvisetus & - & Dinophysis caudata & + \\
\hline Chaetoceros dadayi & - & Diplopsalis complex & - \\
\hline Chaetoceros danicus & + & Goniaulax polygramma & - \\
\hline Chaetoceros diversus & + & Goniaulax sp. & - \\
\hline Chaetoceros lorenzianus & - & Goniodoma acuminatum & + \\
\hline Chaetoceros rostratus & - & Gymnodinium sp. & - \\
\hline Chaetoceros socialis & $+/ a$ & Gyrodinium fusiforme & - \\
\hline Chaetoceros sp. & - & Gyrodinium sp. & - \\
\hline Chaetoceros tetrastichon & - & Hermesinium adriaticum & + \\
\hline Chaetoceros tortissimus & - & Heterocapsa sp. & - \\
\hline Chaetoceros vixvisibilis & + & Kofoidinium velelloides & - \\
\hline Chaetoceros wighami & - & Minuscula bipes & - \\
\hline Chateoceros contortus & + & Oxyphysis oxytoxoides & + \\
\hline Coscinodiscus oculus iridis & - & Oxytoxum caudatum & - \\
\hline Coscinodiscus sp. & - & Oxytoxum sceptrum & - \\
\hline Cyclotella sp. & + & Oxytoxum variabile & - \\
\hline Cylindrotheca closterium & - & Phalacroma biceps & - \\
\hline Dactyliosolen mediterraneus & - & Phalacroma rotundatum & - \\
\hline Diploneis bombus & - & Podolampas elegans & - \\
\hline Eucampia cornuta & + & Prorocentrum compressum & - \\
\hline Guinardia flaccida & + & Prorocentrum micans & - \\
\hline Guinardia striata & - & Prorocentrum minimum & - \\
\hline Hemiaulus hauckii & + & Prorocentrum triestinum & - \\
\hline Leptocylindrus danicus & + & Protoperidinium brochii & - \\
\hline Leptocylindrus minimus & - & Protoperidinium conicum & - \\
\hline Licmophora sp. & - & Protoperidinium diabolus & + \\
\hline Lioloma pacificum & + & Protoperidinium divergens & - \\
\hline Navicula sp. & - & Protoperidinium leonis & - \\
\hline Nitzschia incerta & - & Protoperidinium ovum & - \\
\hline Paralia sulcata & - & Protoperidinium pallidum & + \\
\hline Pleurosigma sp. & + & Protoperidinium paulseni & - \\
\hline Pseudonitzschia spp. & + & Protoperidinium pyriforme & - \\
\hline Rhizosolenia alata f. gracillima & + & Protoperidinium solidicorne & - \\
\hline Rhizosolenia alata var. indica & - & Protoperidinium steinii & - \\
\hline Rhizosolenia calcar-avis & + & Protoperidinium tuba & - \\
\hline Rhizosolenia fragilissima & + & Pseliodinium vaubanii & - \\
\hline Rhizosolenia imbricata & + & Pyrocystis lunula & - \\
\hline Rhizosolenia robusta & - & Scripsiella sp. & - \\
\hline Rhizosolenia sp. & - & Torodinium sp. & - \\
\hline Rhizosolenia stolterfothii & - & & \\
\hline Skeletonema marinoi & + & & \\
\hline Striatella unipunctata & - & & \\
\hline Thalassionema nitzschioides & + & & \\
\hline Thalassiosira angulata & - & & \\
\hline Thalassiosira sp. & + & & \\
\hline Thalassiothrix frauenfeldii & - & & \\
\hline
\end{tabular}

ELF labelled, with exception of Chaetoceros sp. in August at SJ101. However, at both stations, during summer a variety of species with relatively high contribution to the diatom community did not show any ELF signal.

A variety of species with minor contribution and no detectable ELF signal ("Other not ELF labelled", Figs. 5 and 6) were found at both stations during all sampling terms (Table 1 ).

Dinoflagellates were scarcely ELF labelled (Table 2). The labelled species made up $3-10 \%$ of the dinoflagellate community in June and August, but generally labelled species contributed less than $2 \%$ to the dinoflagellate community. Dinoflagellates in total generally contributed $<10 \%$ to the microphytoplankton abundance.
In October no ELF signal was detected in any microphytoplankton species.

The contribution of ELF positive species to the diatom community was strongly correlated with the bulk APA in the $>3 \mu \mathrm{m}$ fraction (phytoplankton APA; $p=0.009$ ), in contrast to species from the dinoflagellates community $(p=0.538)$. Principal Component Analysis (Fig. 7) also indicated a tight relationship between the contribution of ELF positive diatoms and phytoplankton APA. In addition, positive relations with nitrate and temperature, and inverse relations with $\mathrm{PO}_{4}, \mathrm{DOP}$ and salinity were found. The contribution of ELF positive species to the dinoflagellate community was loosely related with phytoplankton APA, but showed strong positive relationship with temperature. ANOVA showed that during P-limitation the contribution of ELF positive species in both diatom and dinoflagellate communities was significantly higher than during period when $\mathrm{P}$ was not limiting $(p<0.001$ and $p=0.014$, respectively).

\section{Discussion}

The seasonal development of bulk APA in 2013 was similar to those described in earlier studies (Ivančić et al., 2009, 2010, 2012). As observed earlier, during periods of high APA, DOP was consumed, and higher temperature and freshwater nitrate input incited, while $\mathrm{PO}_{4}$ repressed APA expression. This strongly indicates a seasonally reoccurring pattern of APA and that DOP is an important source of $\mathrm{P}$ in the region. Maximal hydrolysis rates and P-limitation were found in upper water column where single cell APA in microphytoplankton was identified using the ELF assay. This assay identifies which members of the phytoplankton community express APA, offering substantially enhanced resolution along the size fractionation. This method is being increasingly used to identify single cell APA in field populations (Dyhrman et al., 2002; Lomas et al., 2004; Dyhrman and Ruttenberg, 2006; Ou et al., 2006; Girault et al., 2013).

The distribution of APA across different species was highly variable between sites and seasons. The contribution of ELF positive species to the diatom community generally related with the phytoplankton APA, and a variety of labelled species were observed during P-limitation (Table 1).

During spring freshets, the western area (SJ101) provided conditions with high nutrient availability in which diatoms dominated the phytoplankton community. However, high bulk APA and very fast APA-mediated $\mathrm{PO}_{4}$ turnover time (hereinafter termed $\mathrm{P}$ turnover) implied a severe P-limitation. In such conditions ELF labelled species represented up to $99.7 \%$ of the diatom community. The dominant species Skeletonema marinoi uses APA to create an advantage in the competition for organic P sources. It appears safe to suggest, that expressing APA is a successful strategy for diatoms to compete for organic $P$ under the influence of riverine nutrient input, since at that time they reached the highest abundance during the year.

Markedly different phytoplankton strategies of $\mathrm{P}$ acquisition were found at the eastern area (RV001). In this area, the cyclonic circulation (Artegiani et al., 1997) advects the water from the more southern parts of the Adriatic Sea, with low nutrient content and microphytoplankton abundances (Viličić et al., 2009; Zavatarelli et al., 1998). Contrary to the western area, at the time microphytoplankton community in this area does not experience pronounced fluctuations of nutrient availability. In March low bulk APA and exceptionally high $\mathrm{P}$ turnover time (about $63 \mathrm{~h}$ ) showed that $\mathrm{PO}_{4}$ was not limiting phytoplankton growth. The water column was mixed and a modest phytoplankton biomass, mainly nanophytoplankton, developed on $\mathrm{PO}_{4}$ regenerated during the winter. In the diatom community only few larger species did already express 


\section{SJ101}
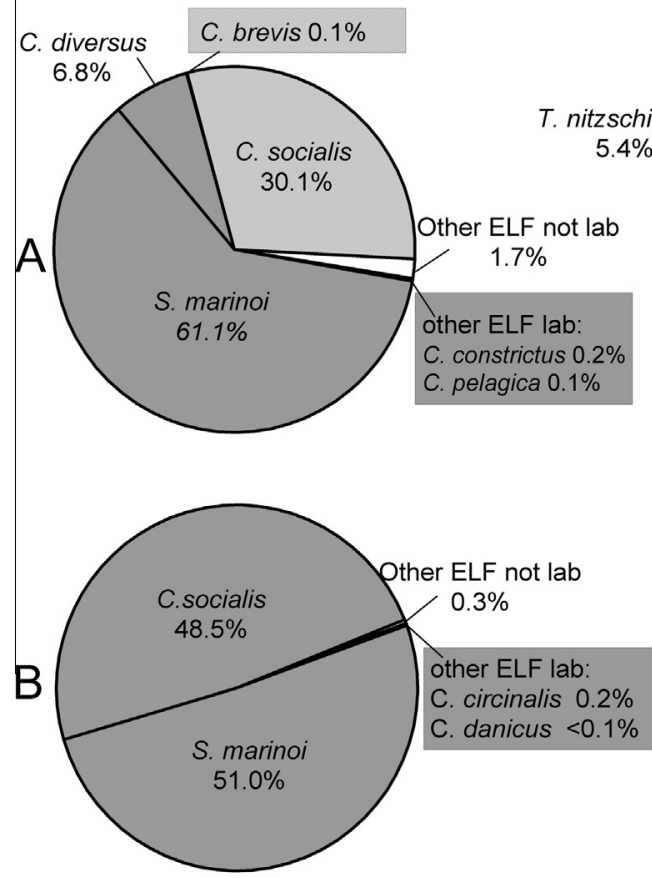

S. marinoi $5.2 \%$

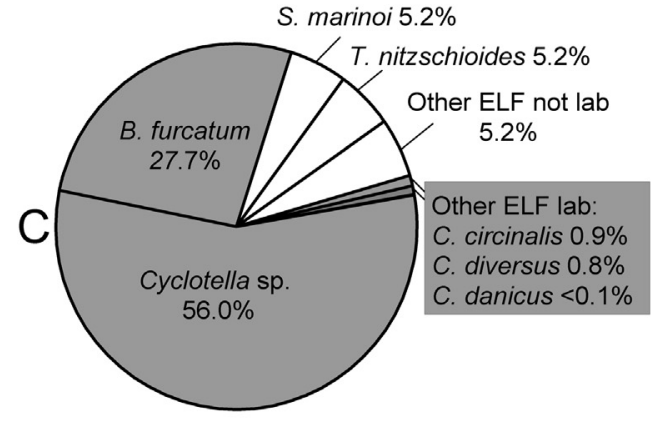

RV001

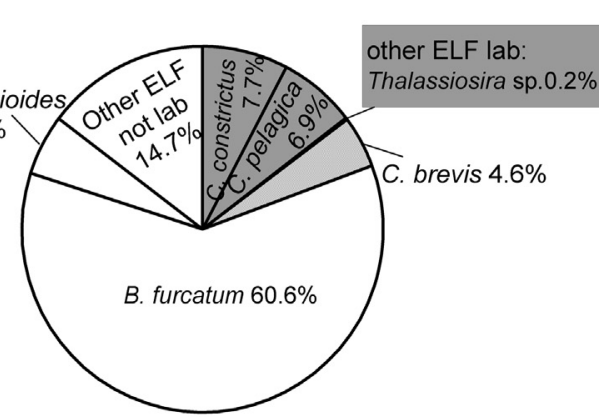

$T$.
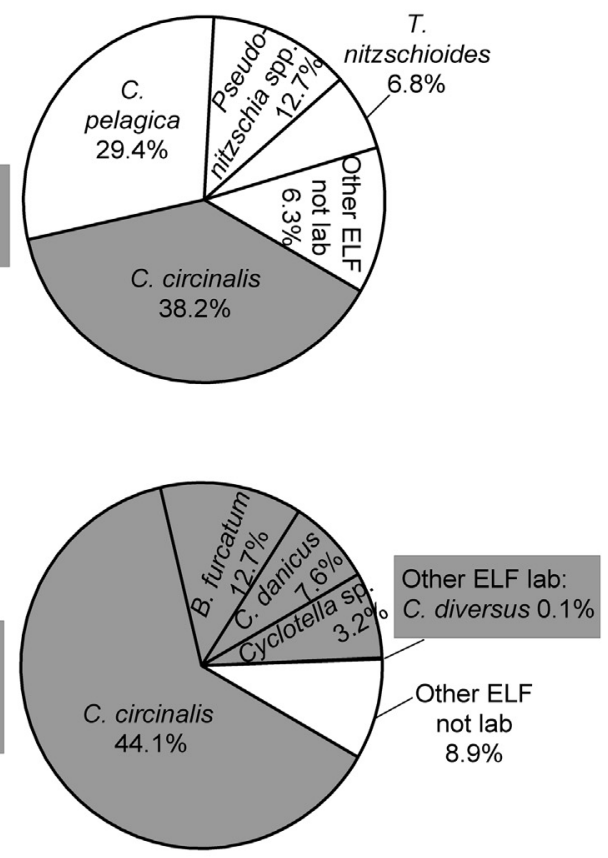

\begin{tabular}{|l|l|l|}
\hline ELF lab & ELF not lab & ELF lab att. bacteria \\
\hline
\end{tabular}

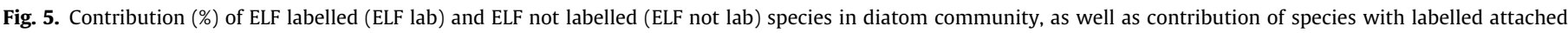
bacteria (ELF lab att. bacteria) in the upper waters (0-10 m) at SJ101 and RV001 in (A) March, (B) April and (C) May 2013.

APA (Chaetoceros constrictus, Cerataulina pelagica and Thalassiosira sp.), indicating them being P-stressed, or even P-limited since their abundance was low. C. pelagica in April did not show any APA signal, indicating that expression of APA in March was due to P-stress/limitation. Probably the other two species follow the same pattern. These larger species have probably a higher half saturation constant of $\mathrm{PO}_{4}$ uptake $\left(K_{\mathrm{m}}\right)$ than the other present species. Larger cells require more nutrients for growth, implicating higher $K_{\mathrm{m}}$ (Eppley et al., 1969) and consequently may be at a disadvantage in nutrient uptake competition compared to smaller phytoplankton. Oh et al. (2010) reported that $K_{\mathrm{m}}$ might be an important index of nutrient affinity as well as a threshold for APA induction. In fact, in oligotrophic conditions found in March at the eastern area, the dominating smaller species Bacteriastrum furcatum (60\% in diatom community) did not express APA. Probably a lower $K_{\mathrm{m}}$ of $\mathrm{PO}_{4}$ uptake and hence an adaptation for success in more oligotrophic conditions, allowed growth of $B$. furcatum without the use of APA. This species co-dominated the diatom community expressing APA in May under P-limited conditions. Consequently, in this species APA regulation according to environmental conditions is supposed. In April P-limiting conditions were observed also at the eastern site and the dominant Chaetoceros circinalis expressed APA to thrive on DOP. However, a variety of diatoms contributed considerably to the overall diatom abundance (about 60\%) without utilizing APA. At the time overall oligotrophic conditions were observed at the eastern site. Hence most of the diatoms did not compete for DOP due to low nutrient availability, but probably slowed down their metabolisms, as supported by their exceptionally low abundances.

From May on phytoplankton communities at both sampling sites share a common history. Typically, at that time of the year the general circulation transports water from the western coast toward the eastern coast, where the current turns northwards (Russo et al., 2005; Lyons et al., 2007), considerably reducing the influence of southern Adriatic waters at the eastern area. In such circumstances, microphytoplankton developed near the western coast under considerable influence of riverine nutrient input, subsequently reach the eastern area. Consequently, both sampling sites show microphytoplankton communities under the influence of unbalanced nutrient input. At the western site, species experienced the unbalanced nutrient input directly, and under nutrient rich conditions they grew to larger numbers exhausting 

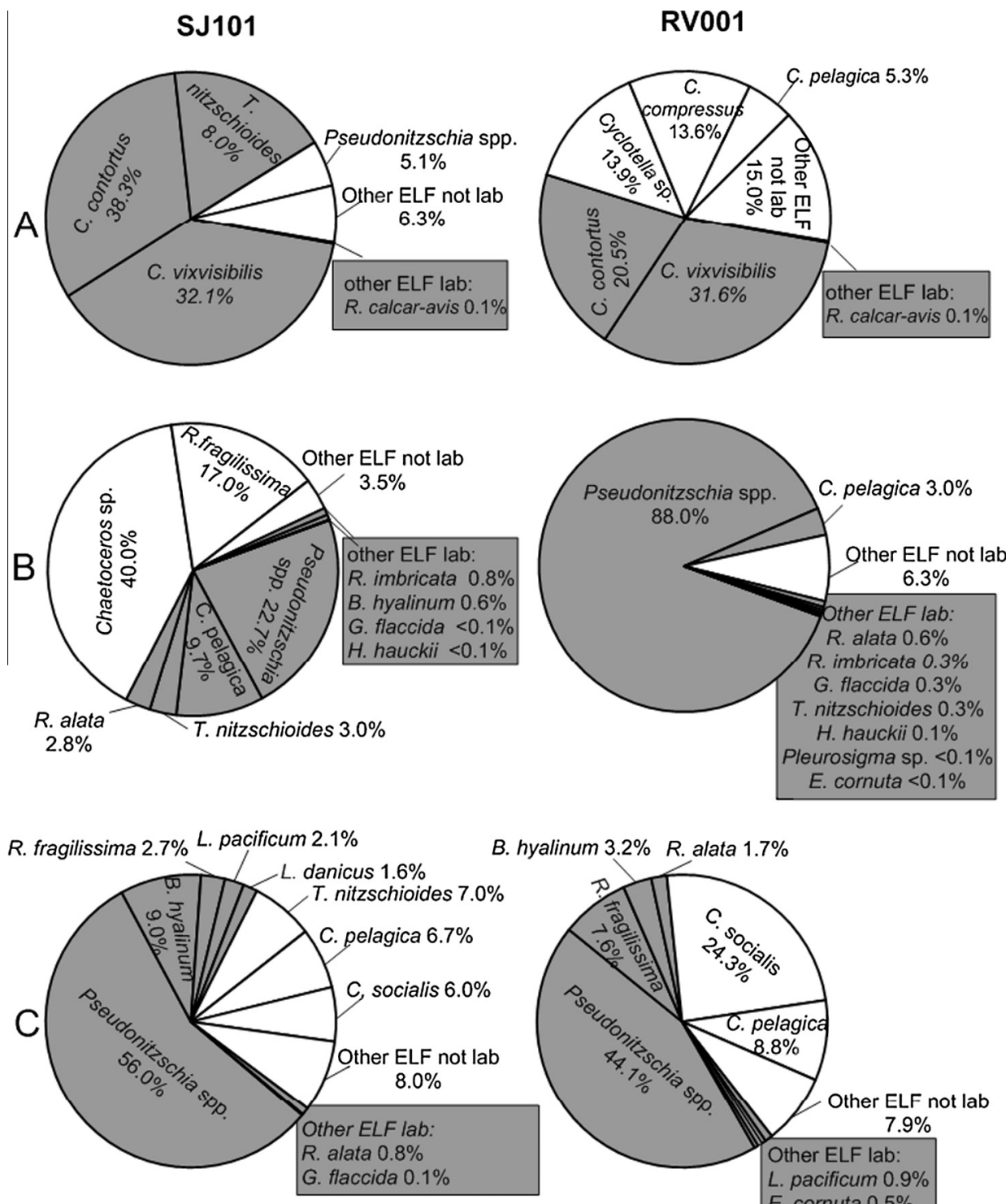

B. hyalinum $3.2 \%$ R. alata $1.7 \%$

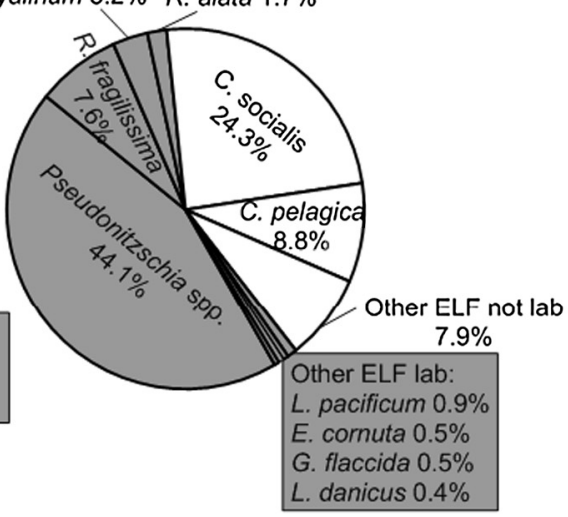

\section{ELF lab}

\section{ELF not lab}

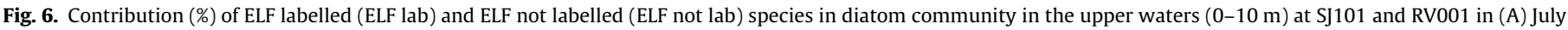
(B), August and (C) September 2013.

Table 2

ELF positive dinoflagellates and their contribution to the dinoflagellate abundance at SJ101 and RV001 during 2013.

\begin{tabular}{ll}
\hline Species & Contribution (\%) \\
\hline Ceratium furca & $0.54-6.99$ \\
Ceratium trichoceros & $0.33-1.72$ \\
Dinophysis caudata & 0.76 \\
Goniodoma acuminatum & 0.64 \\
Hermesinium adriaticum & $0.76-8.17$ \\
Oxyphysis oxytoxoides & 0.64 \\
Protoperidinium diabolus & $0.33-0.64$ \\
Protoperidinium pallidum & 0.81 \\
\hline
\end{tabular}

$\mathrm{PO}_{4}$. Consequently, water spreading toward the east was poor in $\mathrm{PO}_{4}$, but enriched in organic matter produced at the western area. In both cases $\mathrm{P}$-limitation occurred, as confirmed by very fast $\mathrm{P}$ turnover (down to $1 \mathrm{~min}$ ). In such strong P-limited conditions diatoms reacted by expressing APA to sustain (May, July with low abundance), or even to further develop their abundance and activity (August, September, high abundance). As soon as these species again reach the river plume (closed circulation), they will benefit immediately (without lag phase due to dormancy or very low abundances) from the rich nutrient inputs. Additionally, diatoms are known for longer generation times, and hence they would profit from the capability of $\mathrm{P}$ pool formation to compete with faster growing species.

Despite of general P-limiting conditions during the summer, a variety of species that significantly contributed, or even codominated the diatoms community did not express APA. Except for Chaetoceros sp., the other species were found to express APA under at least some conditions. This indicates that those species were not P-limited when found ELF negative. They probably either thrived on intracellular P pools (most likely for species observed at the western site) or had alternative mechanisms to overcome P-limitation (particularly at the eastern site). Possible alternatives indicated by obtained results are (i) the use of $\mathrm{PO}_{4}$ liberated by 


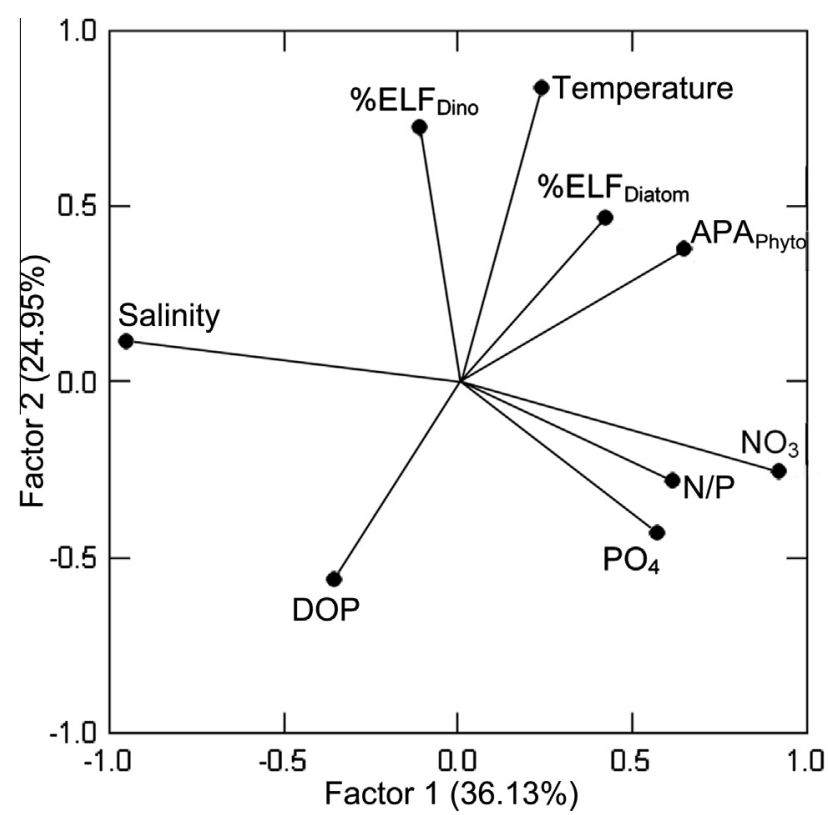

Fig. 7. Principal Component Analysis of measured variables: temperature, salinity, orthophosphate $\left(\mathrm{PO}_{4}\right)$, nitrate $\left(\mathrm{NO}_{3}\right)$, dissolved organic phosphorus (DOP), inorganic $\mathrm{N}: \mathrm{P}$ ratio $(\mathrm{N} / \mathrm{P})$, contribution of ELF positive species in diatom community $\left(\% \mathrm{ELF}_{\text {Diatom }}\right)$, contribution of ELF positive species in dinoflagellate community $\left(\% \mathrm{ELF}_{\text {Dino }}\right)$ and APA in fraction $>3 \mu \mathrm{m}\left(\mathrm{APA}_{\text {Phyto }}\right)$. free/attached enzymes from different species and (ii) the production of non-phospholipids (Ivančić et al., 2012; Van Mooy et al., 2009). During P-limitation, Chaetoceros socialis and Chaetoceros brevis did not show APA themselves when bacteria attached to them showed a strong APA signal. Since $C$. socialis was found able to use DOP when $P$ is limiting, it is possible that associated bacteria provided $\mathrm{P}$ for its growth. Nevertheless, it is not possible to exclude, that $C$. socialis (found during freshets at the western area), deposited $\mathrm{P}$ in intracellular pools while it was abundantly available and that at the sampling time the intracellular availability of P did not yet set on the expression of APA. Phytoplankton accumulate $P$ in response to pulses in $P$ supply (Andersen et al., 1991; Tantanasarit et al., 2013; Wasmund et al., 2014) and stored P can ensure numerous divisions (Silkin et al., 2013). P accumulation in the phytoplankton community of the NA was observed in earlier experiments (Ivančić et al., 2004). Furthermore, phospholipid: non-phospholipid ratio at the investigated sites during the summer (P-limitation) was markedly lower than during November (not P-limitation) (Gašparović, unpubl. data). This indicates a preferential synthesis of non-phospholipids during P-limitation, as already reported for the NA (Ivančić et al., 2012).

At the investigated sites a variety of species have not yet been found ELF labelled (Table 1). Except for Chaetoceros sp., they were not successful during P-limitation, contributing $<3 \%$ to the diatom community. This observation again fosters the hypothesis, that APA is a necessary prerequisite for diatom species to maintain larger abundances during P-limited conditions.

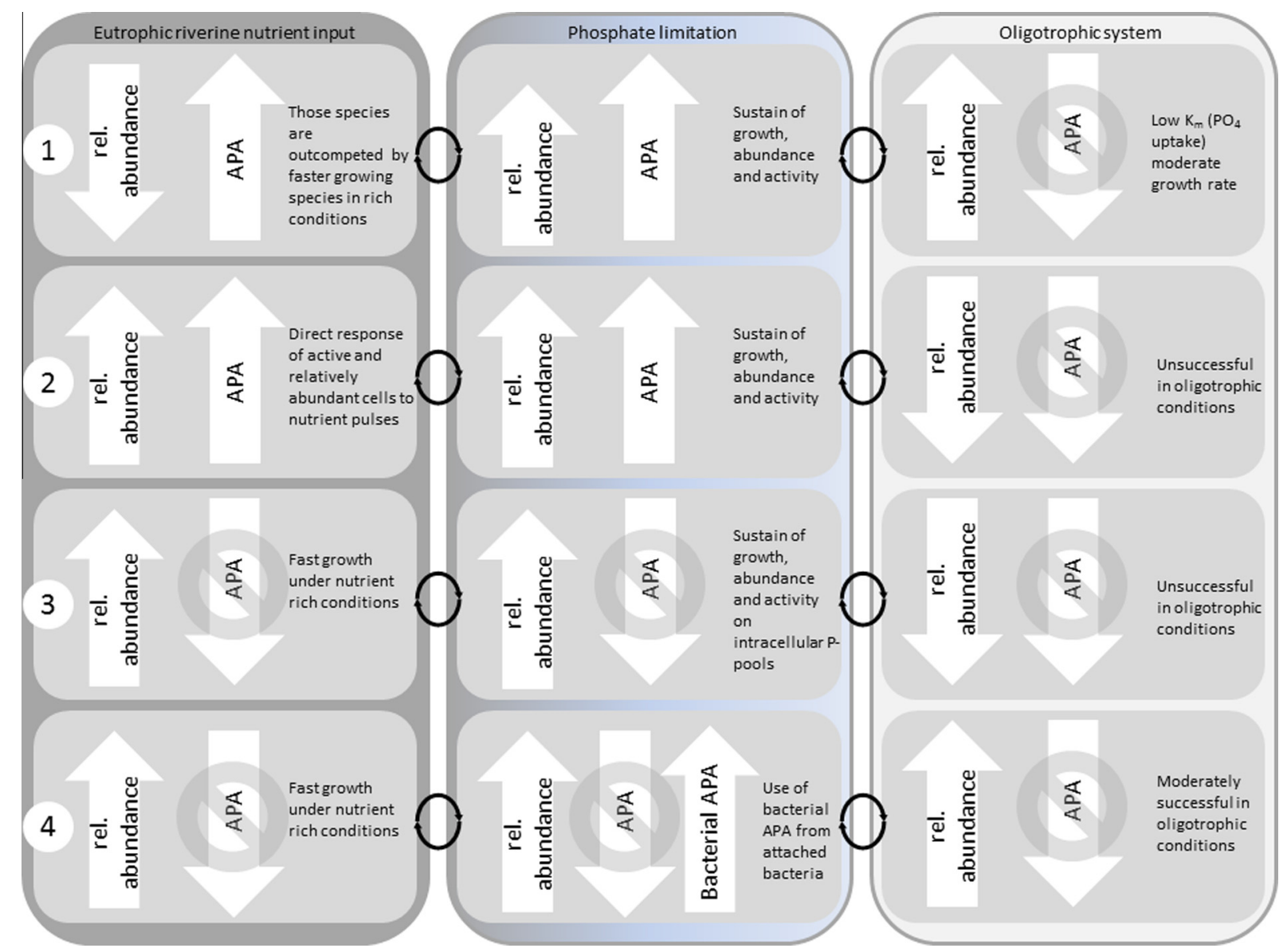

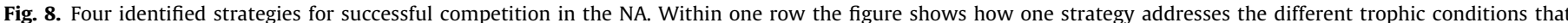

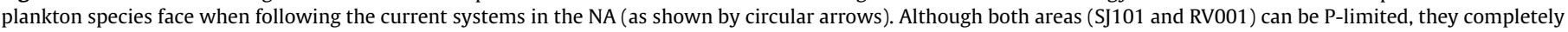
differ in trophic conditions: prevalently eutrophic at SJ101 and more oligotrophic on RV001. 
After the onset of vertical mixing in October, bulk APA decreased being minimal in November when water columns were completely mixed. In these months long P turnover (up to $257 \mathrm{~h}$ ) showed that phytoplankton was not P-limited. During the vertical mixing none of the microphytoplankton species expressed APA. Many of the most abundant species in this period (Lioloma pacificum, Bacteriastrum hyalinum, Rhizosolenia fragilissima, Chaetoceros socialis, Thalassionema nitzschioides, Rhizosolenia imbricata, Skeletonema marinoi, Cyclotella sp.) on the contrary did express APA during the P-limitation in summer. That means there is so far no evidence for APA to be expressed constitutively. APA is rather expressed only when $P$ is limiting, while under other conditions APA is down regulated or not expressed. It seems that during this period the constant supply of $\mathrm{PO}_{4}$ from the bottom prevented P-limitation, as observed earlier (Ivančić et al., 2012).

In the case of dinoflagellates, the contribution of ELF positive species to the community was low regardless of high or low hydrolytic rates or establishment of P-limited conditions. Dinoflagellates expressed APA rarely, and if so, those species had really low abundances (Table 2). Even in May and July, when dinoflagellates approached diatom abundances, only marginal species $(<8 \%$ in dinoflagellate community) expressed APA. This indicates that dinoflagellates in the NA do not employ AP as a means for reaching large abundances. Dinoflagellates did not reach large abundances at the sampled stations, as usual for the investigated area (Godrijan et al., 2013). In contrast to our findings, in other areas a high percentage of dinoflagellates were ELF labelled as reported for the Sargasso Sea (Lomas et al., 2004), Oregon coastal area (Dyhrman and Ruttenberg, 2006), the China Sea (Ou et al., 2006) and subtropical North Pacific (Girault et al., 2013). Some of the reported species in the mentioned areas were identified also in the present study in the NA. Consequently, a low contribution of ELF labelled dinoflagellate species in the respective community in the NA probably does not reflect their inability to employ AP but rather a so far unidentified limitation or possibility, prevent the certain dinoflagellate species from expressing APA. Their reported capability of heterotrophy might make the expression of extracellular APA redundant (Jeong et al., 2010). In fact, the Oregon coast field data indicate that cell-specific APA of dinoflagellates may not be strongly P regulated, and unlike for diatoms, the presence of cell-specific APA does not support an interpretation of $\mathrm{P}$ stress for dinoflagellates (Dyhrman and Ruttenberg, 2006).

\section{Conclusions and future directions}

Overall, in P-limited conditions all species with considerable contributions to the diatom community, with only a few exceptions, expressed APA, while only few dinoflagellate species expressed APA. Diatoms often dominated the phytoplankton community, showing APA to be seemingly a very important prerequisite for their success in the NA. APA-expressing species do not necessarily dominate the phytoplankton community, since species in very low relative abundances that nevertheless did express APA were found. This suggests that APA is also an important strategy for species to survive and maintain active metabolic state outside of their mass abundances or blooms. This allows them to immediately react to short term nutrient availability (e.g. riverine input). This feature appears to be very beneficial in a complex and fast changing environment with gradients of nutrient availability and point sources for nutrient input. Findings of co-dominating species in the diatom community that did not express APA, let presume that those species store P intracellularly, especially at the western site (close to the Po plume), and at the sampling time still lived on those pools. Other species did not express APA themselves, however bacteria attached to those cells did show APA. For these spe- cies a symbiotic relationship could be supposed, where the larger host diatom cell makes use of APA expressed by the attached bacteria.

Further research should address strategies for successful competition of phytoplankton in P-limiting conditions. Such strategies are likely to be found globally. From a variety of possible phytoplankton strategies we propose here 4 of them (Fig. 8) that in the light of results presented herein, authors' experiences and earlier work (Gašparović et al., 2013; Godrijan et al., 2013; Ivančić et al., 2004, 2012; Viličić et al., 2013) appear to be the most plausible.

Strategy 1: Efficient $\mathrm{PO}_{4}$ uptake. $K_{\mathrm{m}}$ for $\mathrm{PO}_{4}$ uptake should be lower than $\mathrm{PO}_{4}$ concentration. Species dominate in oligotrophic conditions without APA when P is not limiting. Cell division time is not essential but rather endurance and uptake efficiency. Such species use APA for survival or bloom formation/prolongation after unbalanced nutrient input.

Strategy 2: Sustaining abundances and activity during P-limitation with APA. Fast bloom formation when nutrients become available due to sustained abundances and active state. The absence of APA in oligotrophic conditions might be due to limitation with other resources.

Strategy 3: Sustaining abundances or bloom formation on P-pools or/and production of non-phospholipids. Species co-dominating in P-limited conditions without APA.

Strategy 4: Symbiotic relationship with bacteria. Species that co-dominate in P-limited conditions without APA, but with attached bacteria that do express APA. When experiencing eutrophic riverine input those species grow fast and co-dominate the community. Under oligotrophic conditions those species are moderately abundant but attached bacteria are virtually absent or do not express APA.

\section{Acknowledgements}

We thank Jasna Jakovčević, Margareta Buterer, and the crew of $\mathrm{R} / \mathrm{V}$ Vila Velebita for help during sampling and analyses. Dr. D.M. Lyons is thanked for English corrections. Three anonymous referees are thanked for their valuable comments and constructive suggestions. This work was a part of the scientific projects 098-0982705-2729 and 098-0982705-2731 funded by the Ministry of Science, Education and Sport of the Republic of Croatia and UIP-2014-09-6563 funded by the Croatian Science Foundation.

\section{Appendix A. Supplementary material}

Supplementary data associated with this article can be found, in the online version, at http://dx.doi.org/10.1016/j.pocean.2016.07. 003.

\section{References}

Andersen, T., Schartau, A.K.L., Paasche, E., 1991. Quantifying external and internal nitrogen and phosphorus pools, as well as nitrogen and phosphorus supplied through remineralization, in coastal marine plankton by means of a dilution technique. Marine Ecology Progress Series 69, 67-80.

Artegiani, A., Bregant, D., Paschini, E., Pinardi, N., Raicich, F., Russo, A., 1997. The Adriatic Sea general circulation. Part II: Baroclinic circulation structure. Journal of Physical Oceanography 27 (8), 1515-1532.

Casey, J.R., Lomas, M.W., Michelou, V.K., Dyhrman, S.T., Orchard, E.D., Ammerman, J. W., Sylvan, J.B., 2009. Phytoplankton taxon-specific orthophosphate (Pi) and ATP utilization in the western subtropical North Atlantic. Aquatic Microbial Ecology 58 (1), 31-44.

Cotner, J.B., Ammerman, J.W., Peele, E.R., Bentzen, E., 1997. Phosphorus-limited bacterioplankton growth in the Sargasso Sea. Aquatic Microbial Ecology 13 (2), 141-149.

Cozzi, S., Giani, M., 2011. River water and nutrient discharges in the Northern Adriatic Sea: current importance and long term changes. Continental Shelf Research 31 (18), 1881-1893.

Dyhrman, S., Palenik, B., 1999. Phosphate stress in cultures and field populations of the dinoflagellate Prorocentrum minimum detected by a single-cell alkaline 
phosphatase assay. Applied and Environmental Microbiology 65 (7), 32053212 .

Dyhrman, S.T., Webb, E.A., Anderson, D.M., Moffett, J.W., Waterbury, J.B., 2002. Cellspecific detection of phosphorus stress in Trichodesmium from the Western North Atlantic. Limnology and Oceanography 47 (6), 1832-1836.

Dyhrman, S., Ruttenberg, K., 2006. Presence and regulation of alkaline phosphatase activity in eukaryotic phytoplankton from the coastal ocean: implications for dissolved organic phosphorus remineralization. Limnology and Oceanography 51 (3), 1381-1390.

Egge, J.K., 1998. Are diatoms poor competitors at low phosphate concentrations? Journal of Marine Systems 16 (3-4), 191-198.

Eppley, R.W., Roger, J.N., McCarthy, J.J., 1969. Half-saturation constants for uptake of nitrate and ammonium by marine phytoplankton. Limnology and Oceanography 14 (6), 912-920.

Gašparović, B., Godrijan, G., Frka, S., Tomažić, I., Penezić, A., Marić, D., Djakovac, T. Ivančić, I., Paliaga, P., Lyons, D., Precali, R., Tepić, N., 2013. Adaptation of marine plankton to environmental stress by glycolipid accumulation. Marine Environmental Research 92, 120-132.

Girault, M., Arakawa, H., Hashihama, F., 2013. Phosphorus stress of microphytoplankton community in the western subtropical North Pacific. Journal of Plankton Research 35 (1), 146-157.

Godrijan, J., Marić, D., Tomažić, I., Precali, R., Pfannkuchen, M., 2013. Seasonal phytoplankton dynamics in the coastal waters of the north-eastern Adriatic Sea. Journal of Sea Research 77, 32-44.

González-Gill, S., Keafer, B.A., Jovine, R.V.M., Aguilera, A., Lu, S., Anderson, D.M., 1998. Detection and quantification of alkaline phosphatase in single cells of phosphorus-starved marine phytoplankton. Marine Ecology Progress Series 164, 21-35.

Hoppe, H.-G., 1983. Significance of exoenzymatic activities in the ecology of brackish water: measurements by means of methylumbelliferyl-substrates. Marine Ecology Progress Series 11, 299-308.

Hoppe, H.-G., 2003. Phosphatase activity in the sea. Hydrobiologia 493 (1), $187-$ 200.

Ivančić, I., Degobbis, D., 1984. An optimal manual procedure for ammonia analysis in natural waters by the indophenol blue method. Water Research 18, 11431147.

Ivančić, I., Degobbis, D., 1987. Mechanisms of production and fate of organic phosphorus in the northern Adriatic Sea. Marine Biology 94 (1), 117-125.

Ivančić, I., Degobbis, D., Pečar, O., Fuks, D., Manganelli, M., Kraus, R., Djakovac, T., Precali, R., Scenati, R., 2004. Northern Adriatic mesocosm experiment Rovinj 2003: nutrient dynamics. Periodicum Biologorum 106 (1), 17-22.

Ivančić, I., Radić, T., Lyons, D.M., Fuks, D., Precali, R., Kraus, R., 2009. Alkaline phosphatase activity in relation to nutrient status in the northern Adriatic Sea. Marine Ecology Progress Series 378, 27-35.

Ivančić, I., Fuks, D., Radić, T., Lyons, D.M., Šilović, T., Kraus, R., Precali, R., 2010. Phytoplankton and bacterial alkaline phosphatase activity in the northern Adriatic Sea. Marine Environmental Reseserch 69, 85-94.

Ivančić, I., Godrijan, J., Pfannkuchen, M., Marić, D., Gašparović, B., Đakovac, T. Najdek, M., 2012. Survival mechanisms of phytoplankton in conditions of stratification induced deprivation of orthophosphate: Northern Adriatic case study. Limnology and Oceanography 57 (6), 1721-1731.

Jeong, H., Yoo, Y., Kim, J., Seong, K., Kang, N., Kim, T., 2010. Growth, feeding and ecological roles of the mixotrophic and heterotrophic dinoflagellates in marine planktonic food webs. Ocean Science Journal 45 (2), 65-91.

Karl, D.M., Yanagi, K., 1997. Partial characterization of the dissolved organic phosphorus pool in the oligotrophic north Pacific Ocean. Limnology and Oceanography 42 (6), 1398-1405.

Karl, D.M., Bidigare, R.R., Letelier, R.M., 2001. Long-term changes in phytoplankton community structure and productivity in the North Subtropical Gyre: the domain shift hypothesis. Deep-Sea Research II 48, 1449-1470.

Karl, D.M., 2007. The marine phosphorus cycle. In: Hurst, C.J. (Ed.), Manual of Environmental Microbiology. ASM Press, Washington, DC, pp. 523-539.

Labry, C., Delmas, D., Herbland, A., 2005. Phytoplankton and bacterial alkaline phosphatase activities in relation to phosphate and DOP availability within the Gironde plume waters (Bay of Biscay). Journal of Experimental Marine Biology and Ecology 318 (2), 213-225.

Larato, C., Celussi, M., Virgilio, D., Karuza, A., Falconi, C., De Vittor, C., Del Negro, P., Fonda Umani, S., 2010. Production and utilization of organic matter in different P-availability conditions: a mesocosm experiment in the Northern Adriatic Sea. Journal of Experimental Marine Biology and Ecology 391 (1), 131-142.

Lomas, M.W., Swain, A., Shelton, R., Ammerman, J.W., 2004. Taxonomic variability of phosphorus stress in Sargasso Sea phytoplankton. Limnology and Oceanography 49 (6), 2303-2310.

Lyons, D.M., Supić, N., Smodlaka, N., 2007. Geostrophic circulation patterns in the Northeastern Adriatic Sea and the effects of air-sea coupling: May-September 2003. Journal of Geophysical Research 112 (C3), 1-17.

Mackey, K.R.M., Labiosa, R.G., Calhoun, M., Street, J.H., Post, A.F., Paytan, A., 2007. Phosphorus availability, phytoplankton community dynamics, and taxonspecific phosphorus status in the Gulf of Aqaba, Red Sea. Limnology and Oceanography 52 (2), 873-885.

Malfatti, F., Turk, V., Tinta, T., Mozetič, P., Manganelli, M., Samo, T.J., Ugalde, J.A., Kovač, N., Stefanelli, M., Antonioli, M., Fonda-Umani, S., Del Negro, P., Cataletto, B., Hozić, A., Ivošević DeNardis, N., Žutić, V., Svetličić, V., Mišić Radić, T., Radić, T., Fuks, D., Azam, F., 2014. Microbial mechanisms coupling carbon and phosphorus cycles in phosphorus-limited northern Adriatic Sea. Science of the Total Environment 470-471, 1173-1183.
Maestrini, S.Y., Berland, B.R., Bréret, M., Béchemin, C., Poletti, R., Rinaldi, A., 1997 Nutrients Limiting the Algal Growth Potential (AGP) in the Po River Plume and an Adjacent Area, Northwest Adriatic Sea: Enrichment Bioassays with the Test Algae Nitzschia closterium and Thalassiosira pseudonana. Estuaries 20 (2), 416429.

Menzel, D.W., Corwin, N., 1965. The measurement of total phosphorus in seawater based on the liberation of organically bound fractions by persulfate oxidation. Limnology and Oceanography 10 (2), 280-282.

Moutin, T., Van Den Broeck, N., Beker, B., Dupouy, C., Rimmelin, P., Le Bouteiller, A. 2005. Phosphate availability controls Trichodesmium spp. biomass in the SW Pacific Ocean. Marine Ecology Progress Series 297, 15-21.

Nausch, M., Nausch, G., Wasmund, N., 2004. Phosphorus dynamics during the transition from nitrogen to phosphate limitation in the central Baltic Sea. Marine Ecology Progress Series 266, 15-25.

Oh, S.J., Kwon, H.K., Noh, I.H., Yang, H.-S., 2010. Dissolved organic phosphorus utilization and alkaline phosphatase activity of the dinoflagellate Gymnodinium impudicum isolated from the South Sea of Korea. Ocean Science Journal 45 (3), $171-178$.

Ou, L., Huang, B., Lin, L., Hong, H., Zhang, F., Chen, Z., 2006. Phosphorus stress of phytoplankton in the Taiwan Strait determined by bulk and single-cell alkaline phosphatase activity assays. Marine Ecology Progress Series 327, 95-106.

Pfannkuchen, M., Marić, D., Godrijan, J., Fritz, G., Brümmer, F., Jaklin, A., Hamer, B., Batel, R., 2009. Sponges (Porifera) and eukaryotic, unicellular plankton. A case study on Aplysina aerophoba, Nardo 1886 in the Northern Adriatic. Journal of Experimental Marine Biology and Ecology 382 (1), 40-46.

Pfannkuchen, M., Schlesinger, S., Fels, A., Brümmer, F., 2010. Microscopical techniques reveal the in situ microbial association inside Aplysina aerophoba, Nardo 1886 (Porifera, Demospongiae, Verongida) almost exclusively consists of cyanobacteria. Journal of Experimental Marine Biology and Ecology 390 (2), $169-178$.

Redfield, A.C., Ketchum, B.H., Richards, F.A., 1963. The influence of organisms on the composition of seawater. In: Hill, M.N. (Ed.), The Sea. Interscience, pp. 27-77.

Russo, A., Maccaferri, S., Djakovac, T., Precali, R., Degobbis, D., Deserti, M., Paschini, E., Lyons, D.M., 2005. Meteorological and oceanographic conditions in the northern Adriatic Sea during the period June 1999-July 2002: influence on the mucilage phenomenon. Science of Total Environment 353 (1-3), 24-38.

Sieburth, J.M., Smetacek, V., Lenz, J., 1978. Pelagic ecosystem structure: heterotrophic compartments of the plankton and their relationship to plankton size fractions. Limnology and Oceanography 23 (6), 1256-1263.

Silkin, V.A., Pautova, L.A., Lifanchuk, A.V., 2013. Physiological regulatory mechanisms of the marine phytoplankton community structure. Russian Journal of Plant Physiology 60 (4), 541-548.

Strickland, J.D.H., Parsons, T.R., 1972. A practical handbook of seawater analysis Bulletin of the Fisheries Research Board of Canada 167, 310.

Tantanasarit, C., Englande, A.J., Babel, S., 2013. Nitrogen, phosphorus and silicon uptake kinetics by marine diatom Chaetoceros calcitrans under high nutrient concentrations. Journal of Experimental Marine Biology and Ecology 446, 6775.

Thingstad, T.F., Skjoldal, E.F., Bohne, R.A., 1993. Phosphorus cycling and algalbacterial competition in Sandsfjord, western Norway. Marine Ecology Progress Series 99, 239-259.

Thingstad, T.F., Zweifel, U.L., Rassoulzadegan, F., 1998. P limitation of heterotrophic bacteria and phytoplankton in the northwest Mediterranean. Limnology and Oceanography 43 (1), 88-94.

Turk, V., Rehnstam, A.-S., Lundberg, E., Hagstrom, A., 1992. Release of bacterial DNA by marine nanoflagellates, an intermediate step in phosphorus regeneration. Applied and Environment Microbiology 58 (11), 3744-3750.

Tyrrell, T., 1999. The relative influences of nitrogen and phosphorus on oceanic primary production. Nature 400, 525-531.

Utermöhl, H., 1958. Zur Vervollkommnung der quantitativen PhytoplanktonMethodik. Mitteilungen des Internationale Vereinigung für theoretische und angewandte Limnologie 9, 1-38.

Van Mooy, B.A.S., Fredricks, H.F., Pedler, B.E., Dyhrman, S.T., Karl, M., Koblıžek, M., Lomas, M.W., Mincer, T.J., Moore, L.R., Moutin, T., Rappe, M.S., Webb, E.A., 2009. Phytoplankton in the ocean use non-phosphorus lipids in response to phosphorus scarcity. Nature 458, 69-72.

Viličić, D., Kuzmić, M., Tomažić, I., Ljubešić, Z., Bosak, S., Precali, R., Djakovac, T., Marić, D., Godrijan, J., 2013. Northern Adriatic phytoplankton response to short Po River discharge pulses during summer stratified conditions. Marine Ecology - an Evolutionary Perspective 34 (4), 451-466.

Viličić, D., Kuzmić, M., Bosak, S., Šilović, T., Hrustić, E., Burić, Z., 2009. Distribution of phytoplankton along the thermohaline gradient in the northeastern Adriatic channel; winter aspect. Oceanologia 51 (4), 495-513.

Wasmund, N., Nausch, G., Hansen, A., 2014. Phytoplankton succession in an isolated upwelled Benguela water body in relation to different initial nutrient conditions. Journal of Marine Systems 140, 163-174.

Xu, J., Yin, K., He, L., Yuan, X., Ho, A.Y.T., Harrison, P.J., 2008. Phosphorus limitation in the northern South China Sea during late summer: influence of the Pearl River. Deep-Sea Research I 55 (10), 1330-1342.

Yamaguchi, H., Adachi, M., 2010. The utilization of organic phosphorus by eukaryotic phytoplankton in marine environments (review). Bulletin of the Plankton Society of Japan 57 (1), 1-12.

Zavatarelli, M., Raicich, F., Bregant, D., Russo, A., Artegiani, A., 1998. Climatological biogeochemical characteristics of the Adriatic Sea. Journal of Marine Systems 18, 227-263. 